\title{
1.2 Community Energy Enterprises: An Interpretative Research Framework for Distributed Energy Policy Making
}

\author{
Luca TRICARICO \\ Department of Architecture and Urban Studies, Politecnico di Milano
}

New technologies for local energy systems have recently reached a degree of maturity that now allows for significant innovations and investments in communitybased initiatives. This paper discusses the possibility of adopting community energy enterprises as a specific organizational model that may represent a crucial and hitherto unexplored tool for enhancing the diffusion of a distributed energy system and thus promoting new urban and regional developments. The crucial issue here is that in a distributed energy system we encounter not only production units, but also the realities of ownership, decision-making and local responsibility, which are interesting factors when discussing new forms of energy provision, infrastructures and organizations. We will take a multidisciplinary look at the role of this specific type of organization that can potentially innovate the governance of the current energy system from the bottom up. It could lead to a sociomaterial transition in the energy market by mobilizing specific territorial factors, institutions and approaches to users' and citizens' engagement.

\section{Community energy enterprises: an introduction to the research framework}

The research framework on community energy enterprises (CEEs) is based on the hypothesis that these organizations can innovate the debate on urban policy and planning while contributing to the diffusion of a distributed energy system by triggering virtuous processes of mobilization of local resources. In fact, they reverse the way we think 
about urban planning policies and practices in both general terms and in specific aspects related to energy issues. Against this background, the CEE research framework intends to answer the following questions: Is the role of these organizations desirable and if so, why? What are the advantages and disadvantages of a distributed energy system based on CEEs? Which "bottom-up" activation policies and tools may be worthwhile to make accessible to everyone?

Following these research questions and based on the author's $\mathrm{PhD}$ thesis, this article aims to outline how the CEE research framework offers an innovative interpretation of the relationships between community-based organizations and the more general debates on planning theory and distributed energy.

The research literature on the subject tends to focus on methodologies and themes that combine the concept of community with the development and experimentation of renewable technologies and sources (Madriz-VArgas et al., 2017; Bauwens et al., 2016). It also discusses the regulatory barriers and incentives capable of triggering local cooperation processes (BYRNE et al., 2017; KERR et al., 2017) and the conditions in terms of socio-economic and political factors that favor local participation and mobilization of community energy initiatives (WirTh 2014; Bomberg \& McEwen, 2012).

Our research framework aims to analyze and define the framework of CEEs from among the various organizations that can be found within the broad category of community energy. CEEs are private organizations based on contracts with participatory and collaborative governance. They can be considered the result of local processes of interest aggregation, dialogue and confrontation between different actors, resource exchange and local advantages caused by territorial proximity.

Therefore, the choice of the interpretative framework for CEEs is also based on the ways in which they can serve as an expedient for discussing different levels of planning, regulation and economic policies that are capable of dealing with the institutional and infrastructural re-organization of a distributed energy production scenario.

\section{Attempting to create a methodology for community energy enterprises}

The methodology of this research framework is based on three tools that are capable of addressing the multi-dimensional perspectives from which CEEs operate. Each of these tools will provide a deeper and interconnected understanding of CEEs: ${ }^{1}$

The methodology was developed within several research activities the author was involved in during the PhD programme in Urban Planning, Design and Policy at the Politecnico di Milano. The main results of these activities can be found in Tricarico $(2017,2016,2015)$ and Moroni \& TRICARICO (2017). 
1) An extensive literature review: on the concepts of community that have criticized the production of planning tools, bottom-up policies and self-organized practices (Moroni, 1997; Fareri, 2009; Aiken et al., 2011; Crosta, 2010; Bailey, 2012; Healey, 2014; vAN HAM et al., 2017). The literature review also addresses the relationship between energy policies and territorial organizations in centralized and distributed energy models of production as well as the advantages and risks regarding the environmental, territorial and institutional externalities shifting towards this model (KIESLING, 2012; Bomberg \& McEwen, 2012; JACOBSON et al., 2017).

2) A review of examples: mainly observed in Italy but also in the UK, Germany and Denmark. We make a comparative analysis of the development conditions (assets, policies, partnerships with local authorities and associations) through semi-structured qualitative surveys of the community of investors and project managers, which also aim at identifying the positive and negative outcomes perceived by the communities (conducted on a sample of $\mathrm{n}=85$ investors). The examples of the EWerk Prad and Comunità Cooperativa are presented in 6.4 section.

3) An analysis of documents and secondary probative evidence: i.e. data, documents, regulations, incentives and public policies. These documents and pieces of evidence can be found in governmental and corporate databases and reports, European Union and national directives and regulations, articles of specialized journals and insights produced by think tanks, national and international agreements and laws that have dealt with CEEs and distributed energy at different scales.

\section{Community energy enterprises: the relevancy of the debate}

\section{Questioning infrastructure planning}

In strategic planning the recognized contribution of networks and infrastructures to local economic development can be considered a 'mantra' in regional and urban policy making (FLYVBJERG, 2007). The organizational and spatial dimension of energy networks and infrastructures influences the shape of urban systems (WILKINSON, 2012) and has strong implications on governance schemes and institutional arrangements (Geissler et al., 2017). The research framework of CEEs is an attempt to question the centralized energy infrastructure planning by comparing its contradictions and outdated institutional setting with the emerging distributed energy scenario based on these organizations. In this view, a potential diffusion of CEEs can directly influence the power of infrastructures by connecting material and immaterial urban elements - from people to objects to information (HANNAM et al., 2006) -, acting as a crucial driver behind urban growth and determining future trajectories of urban and regional developments. 


\section{Community engagement, technological change and energy markets}

The analysis of CEEs intends to contribute to the new landscape of opportunities related to experimental community-led agendas and highlight a new approach in policy making towards what some scholars define as "institutional liberalism" (WiLLs, 2016). It will provide both theoretical and empirical findings in order to tackle the 'antipolitics' arguments that are made when dealing with community entrepreneurship. These arguments often serve as a pretext for central governments to reduce their intervention in enterprises regarding social welfare and economic equality and instead leave the decisions and responsibilities up to local residents. It also seems important to explore how CEEs develop their organizational forms within specific frameworks that are determined by specific institutional and market conditions and how these structural aspects influence the broad political context in favor of community action (BOMBERG $\&$ McEwen, 2012). The introduction of a community-led agenda and policy measures enable CEEs to function as polycentric units of energy production. This aspect must surely be taken into account alongside the developments of the platform economy and digital marketplace as a totally new field of action for community-based organizations, with both opportunities and threats. ${ }^{2}$

\section{Dealing with sustainable development and renewable energy agendas}

The third relevant point to explore regards the implications and benefits of enhancing local community access in the energy sector, particularly as a crucial factor for the "low carbon challenge" by promoting different forms of energy efficiency and as a measure to combat climate change (KUZEMKO et al., 2016). In urban areas, commercial, industrial and residential buildings are still highly dependent on traditional energy resources such as oil, coal or gas. Over $80 \%$ of the total primary energy demand still relies on fossil fuels with a significant share going into the built environment of our cities (International Energy Agency, 2015: 25-27). The promotion of an institutional environment that can spread sustainable production and efficiency based on CEE initiatives (SEYFANG, 2010) can also influence built environments, which are usually organized according to energy resources and energy power systems (AlBERTI, 1999).

\footnotetext{
2 Thus, we argue that one of the reasons why CEEs are value-creating is mainly because they can promote both inclusion and competition through the promotion of the diffusion of decentralized and polycentric market processes. Crowdfunding, for instance, shows that platforms can also serve as an inclusive basis for lasting businesses and important innovations. Moving from an expert-led process to a platform approach increases diversity and leads to high quality results and to successful outcomes in general (MoLLick, 2016). This observation highlights an overlooked and under-appreciated aspect of digital market platforms, and the reason why such technologies, services and business models are welfare-enhancing is precisely because of their ability to produce incremental benefits through the aggregation of diffused and local knowledge at lower costs (KIESLING, 2012; IKEDA, 2004).
} 
The form of the built environment is also influenced by the nature of its fuel supply (Droege, 2002). The transition from centralized systems based on fossil fuel to more decentralized ones based on renewable resources will therefore also have an important effect on spatial configurations. In a European perspective, the energy production of many EU countries, including Italy (International EnERgy AgEncy, 2017), are still far from the new conditions outlined in the updated EU directive 2020 climate and energy package (EUROPEAN UNION, 2012). These measures have been integrated into the 2030 climate and energy framework, which was adopted by EU leaders on November 2016 (European Union, 2016). The 2030 climate and energy framework sets three key targets for the year 2030: an at least 40\% reduction in greenhouse gas emissions (from 1990 levels), an at least $27 \%$ share of renewable energy sources and an at least $27 \%$ improvement in energy efficiency. It will be difficult to achieve these goals without overcoming the current oligopolies in the energy market, without promoting regulatory frameworks that facilitate decentralization and without new policies that support the transition from a passive energy society to an active one. The same scenario was hypothesized by the German researcher and parliamentarian Hermann SCHEER ${ }^{3}$ in his famous essay "The Imperative Energy: 100 Percent Renewable Now". SCHEER (2002) argued that extensive use of renewable sources can only be implemented through many independent initiatives in many different places by reconsidering the entire infrastructural system and redistributing market opportunities.

\section{Two examples of CEEs}

\section{Comunità Cooperativa}

The community cooperative of Melpignano near the southern city of Lecce (Apulia region) was created to handle a solar energy production network via photovoltaic panels mounted on the roofs across the city. This third-party ownership scheme of a community cooperative is an experimental form of organization entrusted with managing the local assets and services (TRICARICO, 2014; Legacoop, 2011). According to the cooperative's statute (art. 5), this body was appointed to install the plants and attend to their upkeep, managing the production of energy via smart metering tailored to the needs of the end-users and selling any excess energy back to the market. In truth, the company offers a potential multi-utility structure, inasmuch as its activities include the distribution and supply of combustible gas and water resources, together with management of the services offered by the energy grid. From a legislative point of view, the setup could be reconfigured as a normal mixed cooperative (which comprises production and consumption at the same

3 SCHEER has been one of the main protagonists in the process of promoting renewable energy policies in Germany in recent years. (Jacobsson \& Lauber, 2006). 
time). Thanks to the joint efforts of three partners, a unit was created to run operations through a signed agreement comprising the municipal administration of Melpignano, the Officina Creativa of Lecce (which coordinates activities) and the University of Salento (which drew up a feasibility study for installing banks of photovoltaic cells on rooftops in Melpignano that identified around 180 households with a suitable roof, as well as a schedule for implementing the project). Installation of the cooperative plants in Melpignano was made feasible by the detached single-unit housing typology with accessible roofs (each household ceded use of its roof to the cooperative for a period of 20 years and received free energy in return). As for the financial resources needed, these came from the "Copfond" (one of Legacoop's ventures), the "Banca Etica", a third-party owner (the cooperative itself) and partly through a subscription fee paid by members. With these funds the cooperative has managed to repay the interest on the initial outlay, and it has also created its own savings fund. The earnings derived from the investment are used according to the decision made during the periodical assemblies of the members. So far, they have been allocated to urban regeneration, such as improving green space, resurfacing roads, school bus services and school cafeterias.

\section{EWerk Prad}

The EWerk Prad cooperative was created in the municipality of Prato allo Stelvio (Trentino-Alto Adige region) (Legambiente, 2015). It has about 1,150 members $(90 \%$ of the local users). In 1925 the Italian national grid did not serve the locality; it was then that, by necessity, the community started to experiment with energy independence with a small hydropower plant (1926). The demand for electricity and heat is now satisfied by renewable sources: 5 mini-hydroelectric plants and 4 plants fueled by biomass from local sources, wind, solar thermal and photovoltaic installations. The cooperative itself owns and manages the plants and the power grid. The electric grid consists of 64.5 kilometers of low and medium voltage lines. This reduces utility costs (members of the cooperative pay $30-35 \%$ less than current prices for their electricity), which positively impacts the local economy. The local community is entirely independent in terms of energy. The local cooperative is going to provide broadband telecommunication services via optical fibers. Following this first phase, the objective is to develop a local smart grid. The local electricity system can operate in connection with the national grid as well as off-grid. The latter option, for example, made it possible to avoid the consequences of the severe blackout that hit Italy in 2003 . The cooperative produces more energy than is consumed locally - the annual electricity surplus is at a full $50 \%$. The profits earned by the cooperative from selling the excess electricity are partly redistributed through discounts for members and reinvested in the plants. 


\section{Concluding remarks}

Currently, there are two open questions that make us look forward to future investigations and research on the CEE framework:

The first question regards the possibility of extending surveys to a large sample of CEEs. In a larger sample it would be possible to expand the spectrum of the description in different organizational and territorial settings, with new and unexpected results depending on the various contexts. Through robust quantitative analysis, it may be possible to test different features of CEEs and their results in terms of policy outcomes, development conditions and financial issues. At the same time, it may possible to observe different behaviors among the participation dynamics in CEEs in terms of social preferences, environmental awareness and benefits perceived.

The second question discusses the necessity to compare CEE organizations, policy making and distributed energy scenarios in both European and global perspectives. Aside from few exceptions of these kinds of studies this comparison can be crucial for a deeper understanding of this sector.

\section{References}

Aiken M., Cairns B., Taylor M., \& Moran R. (2011), Community organisations controlling assets: a better understanding. Joseph Rowntree Foundation. https://www.jrf.org.uk/report/ community-organisations-controlling-assets-better-understanding [Last accessed on 01-112017]

Alberti M. (1999), Urban Patterns and Environmental Performance: What Do We Know? Journal of Planning Education and Research 19, pp. 151-163.

BAILEY N. (2012), The role, organisation and contribution of community enterprise to urban regeneration policy in the UK. Progress in Planning 77(1), pp. 1-35.

Bauwens T., Gotchev B., \& HolstenKamp L. (2016), What drives the development of community energy in Europe? The case of wind power cooperatives. Energy Research \& Social Science 13, pp. 136-147.

Byrne R., Byrne S., Ryan R., \& O'Regan B. (2017), Applying the Q-method to identify primary motivation factors and barriers to communities in achieving decarbonisation goals. Energy Policy 110, pp. 40-50.

Bomberg E., \& McEwen N. (2012), Mobilizing community energy. Energy Policy 51, pp. 435444.

Crosta P.L. (2010), Pratiche. Il territorio "è l'uso che se ne fa". Milan, Franco Angeli.

Droege P. (2002), Renewable Energy and the City: Urban Life in an Age of Fossil Fuel Depletion and Climate Change. Bulletin of Science, Technology \& Society 22(2), pp. 87-99.

European Union (2016), Climate and Energy Framework. https://ec.europa.eu/clima/policies/ strategies/2030_en [Last accessed on 01-02-2018] 
European Union (2012), Climate and Energy Package. https://ec.europa.eu/clima/policies/ strategies/2020_en [Last accessed on 01-02-2018]

FARERI P. (2009), Rallentare: Il disegno delle politiche urbane. Milan, Franco Angeli.

FlyvbJeRg B. (2007), Policy and planning for large-infrastructure projects: problems, causes, cures. Environment and Planning B: Planning and Design 34(4), pp. 578-597.

Geissler J. B., Tricarico L., \& Vecchio G. (2017), The construction of a trading zone as political strategy: a review of London Infrastructure Plan 2050. European Journal of Spatial Development 64, pp. 1-22.

Hannam K., Sheller M., \& Urry J. (2006), Editorial: Mobilities, Immobilities and Moorings. Mobilities 1(1), pp. 1-22.

Healey P. (2014), Citizen-generated local development initiative: recent English experience. International Journal of Urban Sciences 19(2), pp. 1-10.

IKEDA S. 2004. Urban Interventionism and Local Knowledge. The Review of Austrian Economics 17(2-3), pp. 247-264.

InTERnATIONAL ENERgy Agency (IEA). (2017), World Energy Outlook. https://www.iea.org/ publications/freepublications/publication/WorldEnergyOutlook2016ExecutiveSummary English.pdf [Last accessed on 15-09-2017]

International Energy Agency (IEA). (2015), World Energy Outlook Special Report. http://bit. ly/1 fJufF [Last accessed on 15-09-2017]

Jacobson M.Z., Delucchi M.A., Bauer Z.A.F., Goodman S.C., Chapman W.E., Cameron M.A., Bozonnat C., Chobadi L., Clonts H.A., Enevoldsen P., Erwin J.R., Fobi S.N., Goldstrom O.K., Hennessy E.M, Liu J., Lo J., Meyer C.B., Morris S.B., Moy K.R., O’Neill P.L., Petkov I., Redfern S., Schucker R., Sontag M.A., Wang J., Weiner E., Yachanin A.S. (2017), 100\% Clean and Renewable Wind, Water, and Sunlight All-Sector Energy Roadmaps for 139 Countries of the World. Joule 1(1), pp. 1-14, Elsevier Inc. DOI: 10.1016/j. joule.2017.07.005

JACOBSSON S., \& LAUBER V. (2006), The politics and policy of energy system transformation explaining the German diffusion of renewable energy technology. Energy Policy 34(3), pp. 256-276.

Kerr S., Johnson K., \& Weir S. (2017), Understanding community benefit payments from renewable energy development. Energy Policy 105, pp. 202-211.

KIESLING L.L. (2012), Regulation's Effect on Experimentation in Retail Electricity Markets. The Annual Proceedings of the Wealth and Well-Being of Nations 4, pp. 89-113.

Kuzemko C., Lockwood M., Mitchell C., \& Hoggett R. (2016), Governing for sustainable energy system change: Politics, contexts and contingency. Energy Research \& Social Science 12, pp. 96-105.

Legacoop (2011), Guida alle Cooperative di Comunità. http://bit.ly/2s7z7MD [Last accessed on 15-09-2017]

Legambiente (2015), Comuni rinnovabili. http://www.legambiente.it [Last accessed on 15-092017]

Madriz-Vargas R., Bruce A., \& Watt M. (2017), The future of Community Renewable Energy for electricity access in rural Central America. Energy Research \& Social Science. (In press)

Mollick E. (2016), The Unique Value of Crowdfunding Is Not Money - It's Community. Entrepreneurial Finance. Harvard Business Review. http://bit.ly/23Nao1B [Last accessed on 01-02-2018] 
Moroni S., \& Tricarico L. (2017), Distributed energy production in a polycentric scenario: policy reforms and community management. Journal of Environmental Planning and Management, pp. 1-21. Online first. DOI: 10.1080/09640568.2017.1379957

Moroni S. (1997), Etica e territorio: Prospettive di filosofia politica per la pianificazione territoriale. Milan, Franco Angeli.

Scheer H. (2002), The Solar Economy Renewable Energy for a Sustainable Global Future. London, Earthscan.

Seyfang G. (2010), Community action for sustainable housing: Building a low-carbon future. Energy Policy 38(12), pp. 7624-7633.

Tricarico L. (2014), Imprese di Comunità nelle Politiche di Rigenerazione Urbana: Definire ed Inquadrare il Contesto Italiano. Euricse Working Papers 68, p. 14.

Tricarico L. (2015), Energia come community asset e orizzonte di sviluppo per le imprese di comunità. Impresa Sociale 5, pp. 53-64.

TRICARICO L. (2016), Imprese di comunità come fattore territoriale: riflessioni a partire dal contesto italiano. CRIOS 11, pp. 35-50.

Tricarico L. (2017), Community action: value or instrument? An ethics and planning critical review. Journal of Urbanism and Architecture 41(3), pp. 221-233. DOI: 10.3846/20297955.2017.1355278

Van Ham M., Reuschie D., Kleinhans R., Mason C., \& Syrett S. (eds.), (2017), Entrepreneurial Neighbourhoods: Towards an Understanding of the Economies of Neighbourhoods and Communities. Series: Entrepreneurship, space and place. Cheltenham, Edward Elgar.

WiLkinson C. (2012), Social-ecological resilience: Insights and issues for planning theory, Planning Theory 11(2), pp. 148-169.

WILLS J. (2016), Emerging geographies of English localism: The case of neighborhood planning. Political Geography 53, pp. 43-53.

WIRTH S. (2014), Communities matter: Institutional preconditions for community renewable energy. Energy Policy 70, pp. 236-246. 
